\title{
CREATING ESP CLASSROOM CULTURE BASED ON STUDENT-GENERATED IDEAS
}

\author{
N. Saienko, O. Chugai
}

\begin{abstract}
У статті розглядається проблема трансформації традиційного освітнього середовища $і$ створення класної культури, заснованої на ідеях студентів, які вивчають англійську мову за професійним спрямуванням. Це дослідження проводилося в Національному технічному університеті Украӥни «Київський політехнічний інститут ім. Ігоря Сікорського» зі студентами, щуо спеціалізуються в області інформаційних технологій, математики або фізики, у віці від 18 до 20 років, периого і другого року навчання. Для збору даних використовувалися комбіновані методи, які включали опитування та дискусї, щзо проводилися на добровільних засадах в лютому 2019-2020 навчального року. У статті стверджується, що поетапне введення нових форм навчання, різні типи питань, ігри з визначеннями, Quizlet $i$ Classtime, різні види зворотного зв'язку дозволили викладачам створити середовище, засноване на ідеях, які генеруються студентами, щзо уможливило розвиток самостійності студентів. Таким чином, створення власних матеріалів перетворює студентів на активних учасників, зацікавлених в цілеспрямованому спілкуванні. Викладачі стають фасилітаторами, які допомагають створювати класну культуру, засновану на ідеях студентів. Результати дослідження будуть корисні для практиків, які хотіли б внести зміни в традиційний клас $і$ зробити його орієнтованим на студента
\end{abstract}

Ключові слова: створені студентами, автономія, ігри з визначеннями, питання різного типу, Квізлет, Класстайм, зворотний зв'язок

\section{Introduction}

Rapid development of technology has changed the educational environment and the roles of all participants of the learning process. Educators, who used to inform, explain, control and assess students in a traditional way, discover that they are not in control anymore, unless they accept those changes. Students are not passive recipients anymore, asked or not, they play active roles in class. Therefore, teachers have to explore other approaches to teaching and learning, which are effective in the $21^{\text {st }}$ century. The eclectic approach serves as an umbrella term for the combination of learner-centered teaching, content-centered teaching, reflective teaching, cooperative learning, experiential learning and traditional teaching [1].

The issues of reconsidering the traditional approach to educating people were central for such prominent researchers as Dewey, Kolb, Freire, Hiebert, who focused on the role of the teacher, the importance of experience, responsibilities of learners. However, the problem of exploiting the ideas, generated by ESP students, and defining the ways of creating classroom culture, based on students' ideas, needs further exploration.

\section{Literature review}

There are some incentives for introducing changes in the classroom. One of the recommendations of the British Council's «English for Universities Project» concerning methodology is to shift from teachercentered lessons to student-centered, which is sure to «increase student interaction in the classroom and make more efficient use of contact hours», as well as develop student autonomy in real life situations [2]. «Autonomy» may be defined as an ability of students to think critically, make decisions and act independently, which means that students have more control and responsibilities [3]. In addition to boosting improvements in learning, foreign language competence in particular, studentgenerated activities can transform the future paradigm of the content production by using mobile devices and other gadgets $[4,5]$. Moreover, the pervasiveness of social media, networking sites, modern devices sustains a need of a constant connection with peers, which may be either a problem or an opportunity. Therefore, students' need of social contact and collaboration should be definitely exploited in ESP class [6]. In fact, peer collaboration and inquiry are listed as key pedagogical characteristics of classroom practices in the $21^{\text {st }}$ century [6]. That is why instead of banning, more and more teachers become digitally friendly and welcome gadgets to promote cooperation and research in ESP class. Another incentive for changing ESP classroom culture is a routine, when teachers use their native language to provide explanations. Despite the fact that a grammartranslation approach, popular in 1950s, is not effective in the $21^{\text {st }}$ century classrooms, it is still used. In some cases it can be explained by the presence of «translation tasks and grammar in isolation» tasks in the textbooks [2]. The usage of student-generated activities opens the whole range of possibilities to make the class more interactive 
and efficient while using the «traditional» materials. The issues of content-specific texts, the role of questions in academic textbooks and processes, involved in answering them, are important as they are related to the development of critical thinking [7].

Practically any activity may be done mechanically by students, in many cases the answer does not require a mental activity, for example, in multi-choice test it is possible to choose an option without even reading the task. Therefore, questions as «tools, used for the purpose of stimulating students' text understanding and knowledge building» should be a necessary part of any ESP lesson [7]. Higher-order thinking skills questions (HOTs) require an answer that is stated in the text implicitly, while lower-order thinking skills questions (LOTs) require an answer that is stated explicitly [7]. In order to answer LOTs questions students should turn to the text and find information there; they are also called «WH-questions»; HOTs involve more complicated cognitive processes, when students analyze the information, given in the text, speculate on it and use the hidden meaning or implicit information in order to answer them by comparing, classifying, predicting, etc.

Student-generated materials, aimed at learning new lexical items, help to deal with changing a habit of translating English words into the native language by the students. The point is that a dictionary translation can provide general information about the word, but not about synonyms, antonyms, collocations, etc. [8]. In order to learn new lexical units students should practice using them in different contexts, find ways to memorise them, recall when necessary and use appropriately [8]. Games, which are defined as especially designed activities for putting theory into practice while communicating, revising the material, developing problem-solving skills and creativity, provide that opportunity [9].

Teachers cannot learn for their students, but they can develop professionally and get experience, which is beneficial for students, they can create an environment which promotes learning. It could be done by involving students into various activities, considering their needs, encouraging them to participate, interact with each other: students learn only by doing things themselves and taking full responsibility for their own learning [8]. ESP students, who are knowledgeable in the area of their specialization, think critically, share their experience with others and have discussions, because usually the language teacher has no specific preparation in that specific area of science.

ESP teachers have their own responsibilities anyway: identifying the learning goals, assessing appropriate resources, choosing activities, anticipating student thinking, predicting student strategies, monitoring groupwork, providing feedback, initiating reflection, organizing whole-class discussion, giving students the tools for peer- or self-assessment. From year to year, a lesson implementation will be different as a teacher works with new students, even generations; inevitably, there are new requirements and regurations, technological advances. It is necessary for teachers to become comfortable with unpredictable situations, which is possible if they use an approach built upon students' ideas [10]. The role of a teacher is to facilitate the process of learning on the level of an individual, group and the whole class, which means to guide learners through the series of experiences [11].

One of the most important stages at the end of the lesson is creating some space for critical reflection, which allows students to think about their experience and connect it to what they have learnt at the lesson, evaluate it and make conclusions about new understanding. In this way learning takes place and critical reflection becomes inseparable part of learning experience in the future [12]. There are many ways of facilitating reflection: students may share their thoughts in groups or pairs, verbally or in written form, face-to-face or online, just after the class or later; they may use prompts like questions, finish the sentence or write an essay, related to that experience. For instance, «The Classroom Critical Incident Questionnaire» is used for getting a group anonymous response. At the end of the week a teacher collects students' answers to the questions about their engagement or disengagement in the activities, actions of others, which were helpful or confusing, and at the beginning of the next week shares the group's response in class [13]. Observation, surveys, monitoring and critical reflection give an opportunity for teachers to learn more about students and their interests, identify the difficulties, related to their classroom experience, adjust accordingly in order to meet students' needs and make learning more effective.

\section{The aim and objectives of the study}

The aim of the study was to define the ways of creating ESP classroom culture, which is based on students' ideas. In order to achieve the aim the tasks should be performed: to define the ways of engagement in ESP lessons students prefer and the reasons students provide reflecting on their experience.

To achieve this aim, the following objectives were set:

1. to analyse the effect of adding extentions to the conventional activities;

2. to determine the effectiveness of playing games;

3. to evaluate using technology for exploiting students' ideas in ESP class.

\section{Materials and methods}

This study was conducted at the National Technical University of Ukraine «Igor Sikorsky Kyiv Polytechnic Institute». ESP students, majoring in Information Technology, Mathemathics or Physics, ranged between 18 and 20 years of age, were enrolled in the first and the second year of study.

The ESP course comprised 18 practical classes per semester, with a summative assessment (examination) at the end of the year. A mixed methods research design was used to collect data in order to define ESP students' attitude towards suggested ways of engaging them into generating activities: surveys, which contained open questions, interviews and discussions, conducted on a voluntary basis. The feedback from 42 students was collected during practical classes in February at the beginning of the second semester of 2019-2020 academic year. 


\section{Research results and discussion}

Transforming educational environment did not require changing everything teachers and students usually do in ESP class. One small change like adding an extention to the usual activity, when students prepared tasks for each other, made the difference. For example, after completing the task «The odd one out», «True/False» or «Fill in the gaps» on the topic related vocabulary, the teacher asked students to create similar tasks for each other. They worked in small groups, choosing the words and phrases, designing the activities and checking them for accuracy. Producing their own material, students used their own ideas, imagination, expressed their feelings, attitudes. The fact that what others said or wrote related to their common experiences and individual differences, created the atmosphere of curiosity and interest. For example, features of a real teacher were used in a description of a robot, which triggered a class discussion of qualities, necessary for a good teacher. Making students listen actively was possible by giving them the rubrics, which they used to evaluate the work of others. It was also effective to ask them to summarise what others said, show their attitude, write what they agree or disagree with and why. For example, after writing on the topic of robots vs humans, students provided such feedback: «I agree with the idea of using robots instead of humans as far as safety concerns. I disagree that robots can be left in space for years, because they need to be maintained or charged at least»; «I agree with the thought about all pros of using and applying ROBO pilot, its useful properties are really impressive. To my point of view, RO$\mathrm{BO}$ pilot is perspective, but a human factor such as selfsaving instinct will always win the technologies, the real human is central for the ROBO pilot's work»; «I agree with all information in this writing, because there are true facts. I disagree only with statement that ROBO pilots are reliable, because of unpredictable situations». When students read such comments, they compared their own evaluation with their peers' results. Students were motivated to produce an interesting piece of writing, because they knew that several people would read it and provide feedback, which accords with Little (2016), who found positive influence of students' autonomy on control and responsibilities [3].

Creating questions was one of the studentgenerated activities, based on the text, aimed at checking reading comprehension; on an issue, related to the topic of the lesson, being a pre-speaking or pre-writing activity. In order to prepare questions for each other, students read the text or explored the issue, because first of all the creators of questions had to know the answer themselves in order to assess others. Working in groups, students shared what they already knew, also their background knowledge and personal experience. It was possible to transform asking questions into a game. Before starting a game, all the participants developed the ethical code, decided, which benefits winners had, agreed about the given rules, if necessary, changed them and modified. Students were engaged into creating their own materials for the games they knew and then created new games. Learning the target vocabulary, students played games, based on definitions. Students listened to the descriptions and named the words collecting points for correct answers, individually or in teams. While preparing definitions students could come with several variants like three ways of defining the word «software»: «...the programs, used by a computer», «...the collection of data», or «...something used as the opposite of hardware». Through writing a definition and guessing a word it was possible to learn another additional meaning of a familiar word or phrase, reveal misunderstanding. For example, the definition of «discussion» as «talking with somebody» caused thinking about the differences between discussing something and just talking. The fact that definitions were not taken from a book made others listen carefully in order to catch the meaning. In addition, while repeating the definition several times, students focused on pronunciation and got immediate feedback from others. Students also prepared Taboo cards with the keyword or phrase and taboo words, which had to be excluded from the definition. Teams swaped the sets of Taboo cards, described the keywords for others to name them. For example, the Taboo card, created by students for the keyword «Wi-Fi», presented four taboo words: «network, internet, website, wireless», for the keyword «antivirus» students chose: «software, malware, malicious, Trojans», another option for the same keyword is «computer, program, bugs, Windows». It took efforts to prepare the tasks, but it took much more efforts to define the keyword without using the taboo words. In both cases cheating was not possible, as students created cards by choosing the synonyms, paraphrasing, retrieving the words from their passive. These findings are in keeping with the studies of Tkachova and Tur (2017), who indicated positive influence of games on problem-solving skills and creativity of students [9]. Eventually teachers collected student-generated materials like sets of taboo cards, and created a mini-library of resources, which were possible to use with other students.

Technology opened more opportunities: learning platforms Classtime [https://www.classtime.com] and Quizlet [https://www.quizlet.com] allowed ESP teachers to engage students into creating their own materials online, checking understanding, getting the results visualized. According to the results of the survey, which contained open questions about students' preferences, all students were positive about using Classtime and Quizlet, $41 \%$ could not decide, which was more useful for them, $40 \%$ of respondents defined Quizlet as more benefitial, while $19 \%$ chose Classtime. Some students provided detailed explanations, others just briefly indicated their preferences. The main advantages of Quizlet, highlighted by students, were visuals, which support associative thinking, memorization, increase attention spam, as well as possibility to play games, related to competitiveness, teambuilding, equal participation, regrouping, cooperation, fun. The findings endorse Scrivener's view (2005), who emphasized the importance of manipulating with the words before they become part of students' active vocabulary [8]. At the same time respondents noticed that time limit could be challenging if the words were new for students, it was possible to cheat, a team had to start a new round with the same words, if somebody made a mistake. Proponents of Classtime listed such advantages as learning 
new language in a variety of contexts, working individually at your own pace, checking the answers immediately and getting the results. Some students mentioned development of speaking skills, possibly when they compared the results in groups and discussed the errors. Time limit, only one possibility to answer, no fun were mentioned as disadvantages. Students suggested using Quizlet at the beginning or the end of the lesson, and Classtime in the middle. As soon as students became familiar with these tools, they created their own tests, games, quizzes, added visuals like photos and videos. Using mobile devices allowed students to regroup quickly, when they played games in class, to get access to these resources anywhere anytime, which added time, spent on creating their own materials. These results are consistent with the previous studies, indicating the necessity of collaboration and fun element, expecially when mobile devices are used [2, 4].

\section{Conclusions}

The study revealed several ways of creating ESP classroom culture, based on students' ideas. Using a mixed methods research design it was possible to define the preferable ways of engagement in ESP lessons and the reasons students provided reflecting on their experience.

1. The effect of adding extentions to the conventional activities like asking questions or choosing the odd-one-out was positive: preparing the tasks for each other students expressed the ideas, based on their experience, feelings, attitudes, which created the atmosphere of curiosity and interest.

2 . The effectiveness of playing games like definition games or Taboo was proven by the high level of students' engagement: designing the vocabulary tasks involved all the students, making them compete with each other, following the rules, being creative in order to win.

3. Using technology for exploiting students' ideas in ESP class was highly appreciated by the majority students, who were able to compare and contrast the effectiveness of Classtime and Quizlet in ESP class. The results of the surveys indicated the active role students played, given the opportunity to design the tasks themselves.

\section{References}

1. Chugai O., Terenko O., Ogienko O. Methods that work: best practices of adult educators in the USA // Advanced Education. 2017. Vol. 4, Issue 8. P. 72-77. doi: http://doi.org/10.20535/2410-8286.109216

2. Bolitho R., West R. The internationalisation of Ukrainian universities: the English language dimension: British Council, Ukraine English for Universities Project. 2017. URL: http://www.britishcouncil.org.ua/sites/default/files/2017-10-04_ukraine_-_report_h5_en.pdf

3. Little D. Learner Autonomy 1: Definitions, Issues and Problems. Dublin: Authentik, 1991. URL: https://www. researchgate.net/ publication/259874253

4. Ariffin S. A., Sidek S. F., Mutalib M. F. Preliminary Descriptive Insights into Student Generated Activities for STEM subjects through Mobile Learning in a Malaysian University Context // International Journal of Academic Research in Business and Social Sciences, Human Resource Management Academic Research Society, International Journal of Academic Research in Business and Social Sciences. 2018. Vol. 8, Issue 2. P. 523-534. URL: https://ideas.repec.org/a/hur/ijarbs/v8y2018i2p523-534.html

5. Stavytska I. The formation of foreign language competence of engineering students by means of multimedia // Advanced Education. 2017. Vol. 3, Issue 7. P. 123-128. doi: http://doi.org/10.20535/2410-8286.95301

6. Understanding innovative pedagogies: key themes to analyze new approaches to teaching and learning /Peterson A., Dumont H., Lafuente M., Law N. // OECD Education Working Paper No. 172. 2018. URL: http://www.oecd.org/officialdocuments/ publicdisplaydocumentpdf/?cote=EDU/WKP(2018)8\&docLanguage $=$ En

7. Kiszczak A. The Learning Potential of Study Questions in TEFL Textbooks // Working with Text and Around Text in Foreign Language Environments. Springer, 2016. P. 57-73. doi: http://doi.org/10.1007/978-3-319-33272-7_4

8. Scrivener J. Learning teaching. Macmillan Education, 2015. URL: https://archive.org/stream/ LearningTeachingJ.ScrivenerCopy/Learning\%20Teaching-\%20J.\%20Scrivener_djvu.txt

9. Tkachova N., Tur O. Didactic game as an advanced method of communicative competence formation in future specialists in documentation and information services // Advanced Education. 2017. Vol. 3, Issue 7. P. 141-145. doi: http://doi.org/10.20535/2410-8286.90021

10. Fuentes S. Q. A Lesson Based on Student-Generated Ideas: A Practical Example Highlighting the Role of a Teacher // IUMPST: The Journal. 2011. Vol. 2, Issue Pedagogy. URL: http://www.k-12prep.math.ttu.edu/journal/2.pedagogy/ fuentes01/article.pdf

11. Rothstein D., Santana L. Make just one change: Teach Students to Ask their own questions. Cambridge: Harvard Education Press, 2011. 192 p.

12. The art of being an adult educator. BAEA Becoming Adult Educators in the European Area / Ciantar A., Eesmaa I., Milana M., Lund L. S., Valgmaa R.; ed. by Jääger T. Copenhagen: Danish School of Education, 2010. 60 p. URL: https://www.academia.edu/784439/ The_art_of_being_an_adult_educator

13. Brookfield S. D. The skilful teacher. Wiley, 2015. URL: https://www.ebooks.com/en-ua/book/1895929/the-skillfulteacher/stephen-d-brookfield/?_c=1

Received date 04.05.2020

Accepted date 22.06.2020

Published date 31.07.2020

Nataliia Saienko, PhD, Professor, National Technical University of Ukraine "Igor Sikorsky Kyiv Polytechnic Institute", Peremohy ave, 37, Kyiv, Ukraine, 03056

E-mail: saenko106@gmail.com

Oksana Chugai, $\mathrm{PhD}$, Associate Professor, Department of English for Engineering No. 2, National Technical University of Ukraine "Igor Sikorsky Kyiv Polytechnic Institute", Peremohy ave, 37, Kyiv, Ukraine, 03056

E-mail: ochugai@meta.ua 